\title{
Leder
}

\section{Forskning for forbedret praksis - innen formgiving, kunst og håndverk}

Vi deler mange læreres frykt for at det praktisk skapende arbeidet kan bli nedprioritert i faget Kunst og håndverk $\mathrm{i}$ grunnskolen eller Formgivingsfag $\mathrm{i}$ den videregående skole i Norge ${ }^{1}$. Læreplanene legger imidlertid opp til praktisk skapende arbeid - så frykten må komme fra andre kilder enn læreplanene.

Noen har hevdet at $\varnothing \mathrm{kt}$ forskning innen formgiving, kunst og håndverk bidrar til teoretisering av praksis. Det mener vi er en myte. I de senere årene har både masteroppgaver og doktoravhandlinger innen vårt fagfelt hatt motsatt virkning - de har bidratt til å forbedre praksis. Det gjelder spesielt de doktoravhandlingene som er skrevet av lærere innen formgiving, kunst og håndverk og samisk duodji som: Jorunn Spord Borgen (1998), Liv Merete Nielsen (2000), Gunvor Guttorm (2001), Maja Dunfjeld (2001), Marte Sørebø Gulliksen (2006), Janne Beate Reitan (2007), Berit Ingebrethsen (2008), Ingvild Digranes (2009), Karen Brænne (2009), Nina Scott Frisch (2010), Laila Belinda Fauske (2010), Eva Lutnæs (2011), Biljana Fredriksen (2011), Mari Rorgemoen (2012), Torunn Paulsen Dagsland (2013) og Birte Brekketo (2013). De har alle et innsideperspektiv til undervisning innen fagfeltet.

Av disse vil vi spesielt trekke fram avhandlingen: Standpunktvurdering i grunnskolefaget Kunst og håndverk. Laereres forhandlingsrepertoar skrevet av Eva Lutnæs (2011). Hun har undersøkt hvordan lærere forhandler når de setter standpunktkarakterer i Kunst og håndverk og hun drøfter hvordan de forholder seg til kopi, originalitet, verbalitet og visualitet. Ikke mange leser lange avhandlinger, derfor har Lutnæs også lagt stor vekt på å skrive artikler og innlede på kurs og konferanser om vurderingsproblematikk. Hun har også deltatt i utviklingen av Oslo Kommunes veiledningshefte: Vurdering $i$ kunst og håndverk på ungdomstrinnet: veileder (Ebbestad, Grøstad, Lutnæs, Moe, Stave, \& Egeland, 2009) .

I tillegg til de doktoravhandlingene som er nevnt ovenfor, er det ca. 15 doktorander innen formgiving, kunst og håndverk som forventes å disputere i løpet av de kommende fire år. Og flere kommer. Dette er et forskningsfelt i vekst med røtter tilbake til oppstarten av Hovedfag i Forming i 1976, ved Statens lærerhøgskole i forming Oslo (SLFO) og Statens lærerhøgskole i forming Notodden (SLFN). Disse to tilsvarer nåværende Master i estetiske fag, studieretning Fagdidaktikk - kunst og design ved Fakultet for teknologi, kunst og design, Institutt for estetiske fag ved Høgskolen i Oslo og Akershus (2014) og Master i Formgiving, kunst og håndverk ved Fakultet for estetiske fag, folkekultur og lærerutdanning, Institutt for forming og formgiving på Høgskolen i Telemark (2014) ved studiested Notodden.

Da Jorunn Spord Borgen tok doktorgrad i 1998, banet hun vei for oss andre. Tidsskriftet FORMakademisk (nivå 1) ble opprettet i 2008 med Janne Beate Reitan som redaktør (Reitan, 2008) og fagmiljøet deltar i og organiserer internasjonale konferanser, som DRS//CUMULUS 
Liv Merete Nielsen og Janne Beate Reitan Forskning innen formgiving, kunst og håndverk for forbedret praksis

Oslo 2013 (HIOA, 2013). Dette viser at vi praktikere er godt i gang med å forske innen praktiskestetiske fag. På den måten styrkes også praksis.

\section{Artiklene i dette nummeret}

PhD-student Øivind Røise, Professor Håkan Edeholt og Professor Andrew Morrison, alle fra Institutt for design ved Arkitektur og designhøgskolen i Oslo, samt Førsteamanuensis Cato A. Bjørkli og Professor Thomas Hoff, begge fra Psykologisk institutt, Samfunnsvitenskapelig fakultet ved Universitetet i Oslo undersøker i artikkelen What We Talk About When We Talk About Design. Toward a Taxonomy of Design Competencies om hva designere snakker om når det gjelder sin faglige kompetanse. De har empirisk undersøkt industridesignernes egne antakelser om sin designpraksis i forhold til innovasjon. Ved bruk av en metode som anses som egnet for design forskning, er intervjuuttalelser fra profesjonelle designere kategorisert i 12 forhåndsutvalgte kategorier for det forfatterne tolker som kjernekompetanse innen design.

Askild H. Nilsen, PhD-student ved Institutt for landskapsplanlegging, Norges miljø- og biovitenskapelige universitet (NMBU) har i artikkelen Available outdoor space and competing needs in public kindergartens in Oslo drøftet hvordan endringer i normer og lover påvirker hva som skjer med utnyttelsen av uterom over tid, som grunnlag for planlegging av fleksible utemiljø for barnehager for barn på 1-5 år. Hypotesen var at behov for plass av en mer administrativ karakter, som for eksempel parkering, har blitt prioritert foran lekeområde. Undersøkelsene tyder på at normer grunnlagt i lover vinner striden om plass, selv om dette indirekte svekker barns behov for tilstrekkelige utendørs lekeområder.

Bjørn Magne Aakre, Professor/PhD ved Høgskolen i Nesna og Høgskolen i Telemark har i artikkelen Formgiving, design og håndverk. Fra Reform'94 til Kunnskapsløftet drøftet hvor dyptgripende endringene i struktur og innhold ble, og hvordan har elever og lærere erfart disse endringene $\mathrm{i}$ praksis da Formgivingsfag $\mathrm{i}$ Reform 94 ble delt $\mathrm{i}$ to ved innføringen av Kunnskapsløftet i 2006, i det studiespesialiserende Formgivingsfag og det yrkesfaglig utdanningsprogrammet Design og håndverk. Spørsmålene er søkt besvart med støtte i to kvantitative undersøkelser, en før og en etter innføring av Kunnskapsløftet. Konklusjonene tyder på at de to programmene forble nokså like og at begge fortsatt domineres av jenter, og at design oppfattes å være det sentralt i begge utdanningene.

Harpa Stefansdottir, også PhD-student ved Institutt for landskapsplanlegging, Norges miljø- og biovitenskapelige universitet (NMBU), drøfter $\mathrm{i}$ artikkelen Urban routes and commuting bicyclist's aesthetic experience undersøker om og på hvilken måte estetisk erfaring er involvert i vurdering av kvalitet på syklerutene som informantene har valgt å sykle mellom hjem og arbeid. estetiske erfaringen er først og fremst knyttet til funksjoner som stimulerer følelsesmessig velvære når du sykler. En online undersøkelsen ble gjennomført i tre nordiske byer, Odense, Trondheim og Reykjavik, konsentrere seg om sykling i forskjellige urbane omgivelser. Resultatene fra undersøkelsen tyder på at estetisk erfaring er av verdi for de fleste av respondentene og er derfor av betydning i utviklingen av kvaliteten på sykkelruter for pendling.

Erling Framgard, Høgskolelektor ved Høgskolen i Telemark, Fakultet for estetiske fag, folkekultur og lærerutdaning, Institutt for forming og formgiving har på basis av fagkritiske holdning og sterkt inspirert av dansk billedpedagogikk, utviklet det han kaller Undersøkende praksis (UP). UP er tema- og prosjektorientert bildeundervisning og kan kort karakteriseres som prosessuell og problemløsende, der bildearbeidet blir lagt i et betydningsleie, og der vi forholder oss til at bilder har betydning og fungerer kommunikativt. En vesentlig forståelse er at bilde- 
betydningene framkommer gjennom måten bildet er laget på. I dette arbeidet tilstrebes derfor et bevisst forhold mellom det som uttrykkes i bildene og måten det er uttrykt på. UP forsøker å syntetisere individorientert og disiplinorientert bildepraksis. Denne syntesen knytter seg til en tredje tradisjon som jeg kaller 'Den tredje vei i bildepedagogikken'. UP inkluderer bildedidaktikk, bildeteori og skapende bildepraksis.

Oslo, august 2014

Liv Merete Nielsen og Janne Beate Reitan

Seksjonsredaktør

Ansvarlig redaktør 
Liv Merete Nielsen og Janne Beate Reitan Forskning innen formgiving, kunst og håndverk for forbedret praksis

\section{Referanser}

Borgen, Jorunn Spord. (1998). Kunnskapens stabilitet og flyktighet: om forholdet mellom amatфrer og profesjonelle $i$ kunstfeltet (Doktoravhandling, Det historisk-filosofiske fakultet, Institutt for kulturstudier og kunsthistorie. Universitetet i Bergen.). Bergen: Universitetet i Bergen.

Brekketo, Birte. (2013). Taswir i norsk kontekst: En undersфkelse av hvordan unge norskpakistanske muslimer forholder seg til visuell kommunikasjon med figurative uttrykk (Doktoravhandling, Universitetet i Bergen, Institutt for arkeologi, historie, kultur- og religionsvitenskap). Bergen: Universitetet i Bergen.

Brænne, Karen. (2009). Mellom ord og handling - Om verdsetjing i kunst og handverksfaget (Doktoravhandling, Arkitektur- og designhøgskolen i Oslo, CON-TEXT Vol. 41). Hentet fra http://www.aho.no/Global/Dokumenter/Forskning/Avhandlinger/Braenne_Karen_0909.pdf

Dagsland, Torunn Paulsen. (2013). Eleven som aktфr i dialog med kunst: ungdoms erfaring med kunstundervisningens innhold og metode $i$ faget kunst og håndverk $i$ norsk grunnskole (Doktoravhandling, Åbo Akademi i Vasa, Pedagogiska fakulteten). Hentet fra http://www.doria.fi/bitstream/handle/10024/87921/dagsland_torunn.pdf?sequence=1

Digranes, Ingvild. (2009). Den kulturelle skulesekken: narratives and myths of educational practice in DKS projects within the subject art and crafts (Doktoravhandling, Oslo School of Architecture and Design, CON-TEXT Vol. 38). Hentet fra http://brage.bibsys.no/xmlui/bitstream/handle/11250/93038/1/38_Digranes_avhandling.pdf

Dunfjeld, Maja. (2001). Tjaalehtjimmie: form og innhold i sфrsamisk ornamentikk (Doktoravhandling, Det humanistiske fakultet, Institutt for kunsthistorie, Universitetet i Troms $\varnothing$ ). Troms $\varnothing$ : Universitetet i Troms $\emptyset$.

Ebbestad, Gro., Grøstad, K., Lutnæs, E., Moe, E., Stave, A., \& Egeland, G.G. (2009). Vurdering i kunst og håndverk på ungdomstrinnet. Veileder. Oslo: Oslo kommune, Utdanningsetaten. Hentet fra http://www.utdanningsetaten.oslo.kommune.no/getfile.php/utdanningsetaten\%20\%28UDE\%29/Internett\%2 0\%28UDE\%29/PED/VFL/Kunst_og handverk_101109_final.pdf

Fauske, Laila Belinda. (2010). Arkitektur for grunnskolefaget Kunst og håndverk - fagdidaktiske refleksjoner $i$ kontekst (Doktoravhandling, Arkitektur- og designhøgskolen i Oslo, CON-TEXT Vol. 43). Oslo: Arkitektur- og designhøgskolen i Oslo.

Fredriksen, Biljana. (2011). Negotiating grasp: embodied experience with three-dimensional materials and the negotiation of meaning in early childhood education. (Doktoravhandling, Oslo School of Architecture and Design, CON-TEXT Vol. 50). Hentet fra http://brage.bibsys.no/xmlui/handle/11250/93056

Frisch, Nina Scott. (2010). To see the visually controlled: Seeing-drawing in formal an informal contexts (Doktoravhandling, Norges teknisk-naturvitenskapelige universitet Pedagogisk institutt). Hentet fra http://ntnu.diva-portal.org/smash/get/diva2:318036/FULLTEXT01.pdf

Gulliksen, Marte. (2006). Constructing a formbild. An inquiry into the dynamical and hierarchichal aspects of the hermeneutical filters controlling the formbild construction in design education situations (Doktoravhandling, Oslo School of Architecture and Design., CON-TEXT Vol. 26). Hentet fra http://www.aho.no/global/dokumenter/forskning/avhandlinger/gulliksen_avhandling.pdf

Guttorm, Gunvor. (2001). Duoji bálgát - en studie i duodji: kunsthåndverk som visuell erfaring hos et urfolk (Doktoravhandling, Det humanistiske fakultet, Institutt for kunsthistorie, Universitetet i Troms $\varnothing$ ). Troms $\emptyset$ : Universitetet i Tromsø.

HIOA. (2013). DRS // CUMULUS Oslo 2013. The 2nd International Conference for Design Education Researchers. Hentet fra http://www.hioa.no/eng/About-HiOA/Faculty-of-Technology-Art-and-Design/DRS-CUMULUSOslo-2013

Høgskolen i Oslo og Akershus. (2014). Programplan. Master. Fagdidaktikk-kunst og design. Hentet fra http://www.hioa.no/Studier-og-kurs/TKD/Master/fagdidaktikk-kunst-og-design

Høgskolen i Telemark. (2014). Programplan. Master i Formgiving, kunst og håndverk. Hentet fra http://fagplaner.hit.no/nexusnor/Studier-med-oppstart-2014-2015/Nettvisning/Kunst-og-design/Formgivingkunst-og-haandverk-master 
Ingebrethsen, Berit. (2008). Metaforbasert tegning: unders $\phi k t$ som et bildespråksystem gjennom avistegninger av Finn Graff og Saul Steinberg med kognitiv metaforteori som hovedredskap (Doktoravhandling, Arkitekturog designhøgskolen i Oslo, CON-TEXT Vol. 35). Oslo: Arkitektur- og designhøgskolen i Oslo.

Lutnæs, Eva. (2011). Standpunktvurdering i grunnskolefaget Kunst og håndverk - lareres forhandlingsrepertoar (Doktoravhandling, Oslo: Arkitektur- og designhøgskolen i Oslo, CON-TEXT Vol. 52). Hentet fra http://www.aho.no/PageFiles/1752/Standpunktvurdering\%20i\%20grunnskolefaget $\% 20 \mathrm{Kunst} \% 20 \mathrm{og} \% 20 \mathrm{~h} \%$ C3\%A5ndverk\%20\%E2\%80\%93\%201\%C3\%A6reres\%20forhandlingsrepertoar levert\%20til\%20AHO.pdf

Nielsen, Liv Merete. (2000). Drawing and spatial representations. Reflections on purposes for art education in the compulsory school (Doktoravhandling, Oslo School of Architecture). (CON-TEXT Vol. 2). Oslo: Oslo School of Architecture.

Nielsen, Liv Merete. (2014). Forskning for forbedret praksis. FORM, 48(1), 9.Hentet fra http://media.wix.com/ugd/75f35c_632c5eb135214d4d910e4dc133fcbb5d.pdf

Reitan, Janne Beate. (2007). Improvisation in tradition. A study of contemporary vernacular clothing design practiced by Iñupiaq women of Kaktovik, North Alaska (Doktoravhandling, Oslo School of Architecture and Design, CON-TEXT Vol. 28). Hentet fra http://www.aho.no/global/dokumenter/forskning/avhandlinger/reitan_avhandling.pdf

Reitan, Janne Beate. (2008). Redaksjonelt. Design og designdidaktikk i fokus. FORMakademisk, 1(1), 1-2. Hentet fra https://journals.hioa.no/index.php/formakademisk/article/view/116

Rorgemoen, Mari. (2012). Mellom tradisjon og spel: didaktikk for tekstil folkekunst. (Doktoravhandling, Åbo Akademi i Vasa, Pedagogiska fakulteten). Hentet fra http://www.doria.fi/handle/10024/76673

${ }^{1}$ Lederen bygger på (Nielsen, 2014) 